\title{
Rational Expectations Business Cycles in Search Equilibrium: A Correction
}

\section{Citation}

Diamond, Peter and Drew Fudenberg. 1991. Rational expectations business cycles in search equilibrium: A correction. Journal of Political Economy 99, no. 1:218-219.

\section{Published Version}

http://dx.doi.org/10.1086/261747

\section{Permanent link}

http://nrs.harvard.edu/urn-3:HUL.InstRepos:3190370

\section{Terms of Use}

This article was downloaded from Harvard University's DASH repository, and is made available under the terms and conditions applicable to Other Posted Material, as set forth at http:// nrs.harvard.edu/urn-3:HUL.InstRepos:dash.current.terms-of-use\#LAA

\section{Share Your Story}

The Harvard community has made this article openly available.

Please share how this access benefits you. Submit a story.

Accessibility 


\title{
Confirmations and Contradictions
}

\section{Rational Expectations Business Cycles in Search Equilibrium: A Correction}

\author{
Peter Diamond and Drew Fudenberg \\ Massachusetts Institute of Technology
}

In our recent paper (Diamond and Fudenberg 1989), we asserted that the model given in equation (7) always had some initial conditions for which there were multiple equilibrium paths. In making this assertion, we overlooked a possibility that has been raised in different models by Krugman (1989) and Matsuyama (1989). Although the model economy has three steady-state equilibria, there can be parameters for which there exists a unique equilibrium path from each initial position. This can occur when the middle equilibrium is an unstable node with the saddle-point paths to both of the other equilibria originating in the node. Figure 1 illustrates this possibility. The figure was calculated for parameters $a=1, r=1, c=.009$, and $u=$ .259. In the figure, it is difficult to see the trajectory to the origin since it is very close to the stationary curve, being tangent to that curve at the origin.

In using the Hopf bifurcation to argue for the existence of cycles, we did not cite a specific theorem and may have left the impression that we claimed that cycles occur precisely at the critical value of the interest rate where the real part of the eigenvalues is zero. Theorem 11 in Hassard, Kazarinoff, and Wan $(1981$, p. 16) applies to our system and implies that cycles occur at some interest rate near the critical value. They state (p. 2) that most usually the cycles exist on one side or the other of the critical value and not at the critical value itself.

We are indebted to Olivier Blanchard for questioning the result corrected here, to Kiminori Matsuyama for pointing out the same error and the need for greater precision on the second point, to Doug Galbi for calculations, and to the National Science Foundation for financial support. 


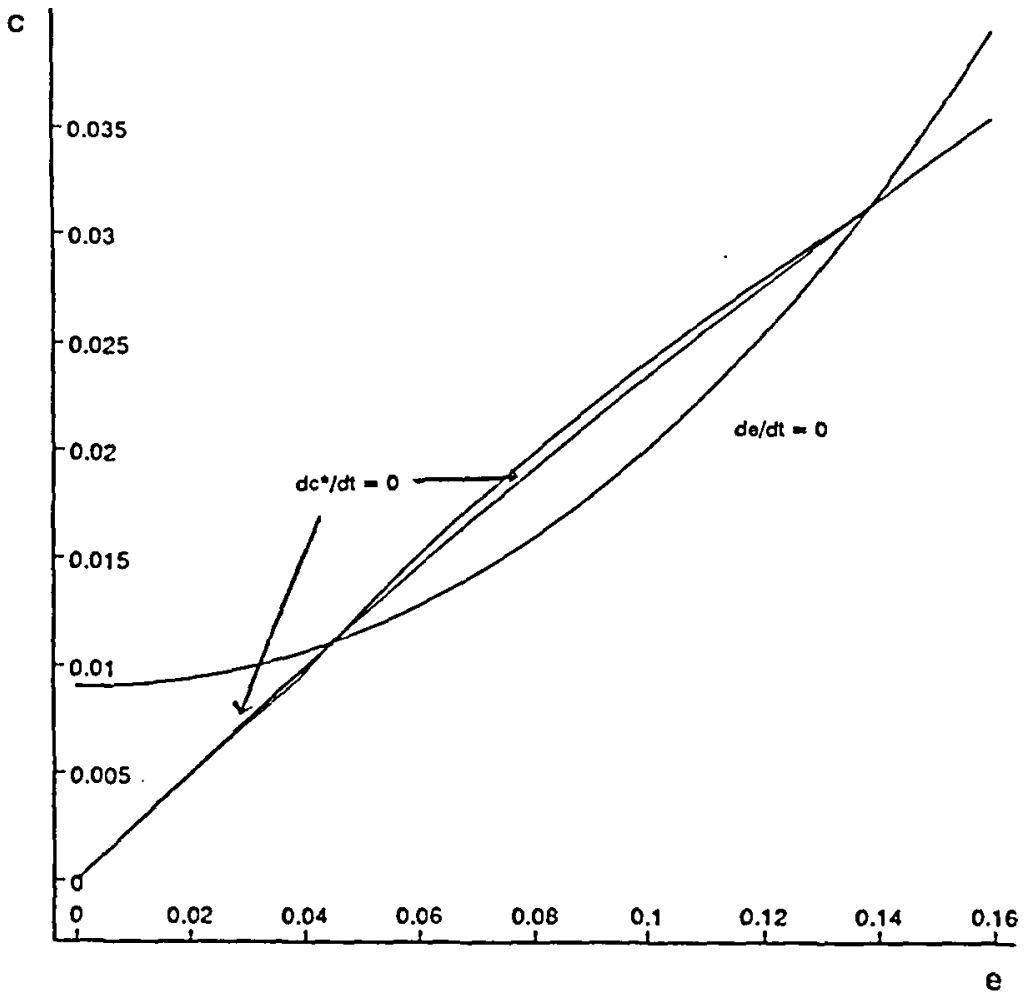

Fic. 1

\section{References}

Diamond, Peter, and Fudenberg, Drew. "Rational Expectations Business Cycles in Search Equilibrium."J.P.E. 97 (June 1989): 606-19.

Hassard, Brian D.; Kazarinoff, Nicholas D.; and Wan, Yieln-Hei. Theoy and Applications of Hopf Bifurcation. Cambridge: Cambridge Univ. Press (for London Math. Soc.), 1981.

Krugman, Paul R. "History versus Expectations." Working Paper no. 2971. Cambridge, Mass.: NBER, May 1989.

Matsuyama, Kiminori. "Increasing Returns, Industrialization and Indeterminacy of Equilibrium." Manuscript. Evanston, Ill.: Northwestern Univ., June 1989. 